\title{
Intervention of Anxiety Self-Therapy Education Media on Clients with Coronary Heart Disease (MD-TEMANKU/MD-MY FRIEND)
}

\author{
Heni Nurhaeni ${ }^{1}$, Dinarti ${ }^{2}$, Suryati ${ }^{3}$, Joko Suwito ${ }^{4}$ \\ 1,2,3 Department of Nursing, Health Ministry, Poltekkes Jakarta I, Indonesia \\ ${ }^{4}$ Department of Nursing, Health Ministry, Poltekkes Surabaya, Indonesia \\ Email: heni_nurhaeni@poltekkesjakarta1.ac.id
}

\begin{abstract}
This research affects the development of independent abilities of clients with coronary heart disease/CHD, in order to reduce the risk of severe occurrence of heart attacks at home due to anxiety with self-relaxation with Video MD-My Friend. This type of research design is an action research with video media, namely MD-My Friend., to $200 \mathrm{CHD}$ clients in the community with a study period of 8 months, using heart rate measurements and anxiety instruments, and univariate analysis, to assess the characteristics of related variables. And bivariate analysis, continued with multivariate analysis on the influence of three meaningful variables. Based on the results of multivariate tests found that the age of the client of $\mathrm{CHD}$ affects knowledge, skills and self-recovery in CHD treatment on the application of MD-My Friend with $P$ Value 0.001 . Worsening of health conditions in coronary heart disease clients who are at risk 6 times with anxiety experienced. So it can be predicted that the risk of death from $\mathrm{CHD}$ cases will increase. As a physiological response that threatens a person's internal physiological state or psychological well-being, anxiety can intervene independently in a good and correct way. Therefore MD-My Friend as one of the alternatives to self-intervention in the Client CHD in order to be able to reduce his anxious condition, which also affects the condition of the CHD. MD-My Friend's video has been shown to have an effect on knowledge, Skills and self-recovery are meaningful.
\end{abstract}

Keywords: Anxiety, Coronary Heart Disease, Video MD My Friend.

\section{A. INTRODUCTION}

Coronary Artery Disease is a general term for plaque buildup in the heart arteries that can cause a heart attack. (American Heart Association, 2017). Clients with coronary heart disease (CHD) often experience anxiety and will worsen his heart health condition significantly (Celano et al., 2016). Anxiety disorders are associated with the onset and progression of heart disease, and in many cases it has been linked to cardiovascular disorders, including the incidence of death. Responding to these conditions and the condition of PJK Clients in the community, researchers consider the importance of educational media innovation that is able to provide alternatives to independent action. In addition to the Client being comfortable, cheap and efficient in its use.

Roring (2019), as the inventor of the first application via online for health insurance claims explained, that the trend of urbanites to reach health access has now shifted. People have been able to find out more about diagnoses by using health application. Hamilton Anxiety Rating Scale (HARS), It was first developed by Max Hamilton in 1956, to measure all signs of anxiety are both psychic and somatic, to measure signs of anxiety in children and adults. Stress in Ressler \& Pine (2015), is a 
physiological response stressors that threaten internal physiological states or wellbeing. Psychological individual. One of them happened to CHD. And with a six-fold risk of death that will cause death, requires prompt handling, efficiency, and easy access by clients who are at home/community.

The development of technology is increasingly impacting mobile device. Media Education Self-Therapy Anxiety Client Coronary Heart Disease (MD My Friend) improves the ability of self-recovery of client health with coronary heart disease (CHD). Media Education Self-Therapy Anxiety Client Coronary Heart Disease (MD Temanku) improves the ability of self-recovery of client health with coronary heart disease (CHD).

\section{B. METHOD}

This type of research design is an action research with video media, namely MD-My Friend., to 200 CHD clients in the community with a study period of 8 months, using heart rate measurements and anxiety instruments, and univariate analysis, to assess the characteristics of related variables. And bivariate analysis, continued with multivariate analysis on the influence of three meaningful variables.

The research arrangement was carried out since the licensing and management of adiministarasi in the region of 4 provinces, and carried out for 8 months. Health Cadres in each region were involved, 100 respondents in each group, especially the intervention group, were monitored with pre and post tests while using MD. As a follow-up, it is expected that the independence of the Client is PJK, and data collection is provided online.

Eligibility criteria are Clients with Coronary Heart problems in the community, can cooperate, have behaviors and attitudes to independently maintain their health and the source of informants is the Health Cadre, as well as the method of selection of respondents implemented by health cadres in their region. The respondents numbered 100 people in each intervention and control group.

Clearly define all outcome variables to be measured. The result variables to be measured, are the previous CHD History, CHD classification, Duration suffering from CHD, Age, Self-recovery ability, SRQ results, results of self-physical examination, CHD knowledge, and CHD handling skills. For each variable of interest, give the sources of data and details of the measurement methods. Questionnaires in nonEnglish languages may also be published as a supplement. If a measurement tool was used, the validity and reliability of the tool should be presented. If a measurement tool developed by other researchers was used, provide a proper citation of the tool and provide permission only if the tool is not freely available to the public. This permission letter should be uploaded during the submission process.

In this study, researchers anticipate the impact of potential bias, namely the involvement of cadres when facilitating when respondents watch MD TEMANKU's video. So that the solution applied to overcome this is that we encourage and always accompany Health Cadres to be objective during intervention activities. 
The MD My Friend video intervention strengthened by Cognitive Behavioral Therapy (CBT) Kerry Ressler, Daniel Pine, (2015) is treatment of choice for anxiety disorders. Before and after the intervention was measured by pre and post tests, to measure the knowledge, skills, and independent abilities of CHD Clients. With a population of 2784064 people, the number of samples is 184 which is divided into 4 provinces in the community (with SS sample size measurement), and Margin of error: $6.51 \%$, meaning, in this case, there is a $95 \%$ probability that the true value is within $\pm 6.51 \%$ of the measured/surveyed value.

The type of research design is action research research using video media, namely MD-TEMANKU, to $200 \mathrm{CHD}$ clients in the community with a study period of 8 months, using heart rate and anxiety measurement instruments (done online via zoom and google applications), and statistical analysis univariate, to assess the characteristics of the related variables. And bivariate analysis, followed by multivariate analysis on the effect of three significant variables. The results of the analysis as shown in the attached table.

\section{RESULTS AND DISCUSSION}

Participants of this study are presented in the following table:

Table 1.a. Distribution of Research Respondents Characteristics ( $n=100)$

\begin{tabular}{|c|l|c|c|c|c|c|}
\hline \multirow{2}{*}{ No } & Variable & Category & \multicolumn{2}{c|}{ Intervention } & \multicolumn{2}{c|}{ Control } \\
\cline { 4 - 7 } & & & Total & $\mathbf{\%}$ & Total & $\mathbf{\%}$ \\
\hline 1 & \multirow{2}{*}{ Previous CHD history } & Yes & 87 & 87 & 99 & 99 \\
& & None & 13 & 13 & 1 & 1 \\
\hline 2 & CHD Classification & APSCCS I & 88 & 88 & 87 & 87 \\
& & APSCCS II & 12 & 12 & 13 & 13 \\
\hline \multirow{2}{*}{3} & Length of time & < 6 Month & 9 & 9 & 17 & 17 \\
& suffering from CHD & 6 Month-<1 Year & 19 & 19 & 35 & 35 \\
& & $1-5$ Year & 36 & 36 & 39 & 39 \\
& & 5 Year & 23 & 23 & 8 & 8 \\
& & None & 13 & 13 & 1 & 1 \\
\hline
\end{tabular}

Table 1.b. Distribution of Research Respondents Characteristics $(n=100)$

\begin{tabular}{|c|c|c|c|c|c|c|c|c|c|}
\hline & & \multicolumn{4}{|c|}{ Intervention } & \multicolumn{5}{c|}{ Control } \\
\cline { 3 - 11 } No & Variable & Mean & Median & Min & Max & Mean & Median & Min & Max \\
\hline 1 & Age & 57.28 & 60 & 19 & 81 & 73.57 & 72.50 & 43 & 88 \\
\hline
\end{tabular}

From the table above, it can be concluded that most of the respondents in the intervention group were 57 years old on average, had a previous history of CHD and currently suffering from CHD is in the second classification and the duration of suffering is more than 1 year to five years. While in the control group, it can be concluded that most of the respondents are 74 years old on average, currently the CHD suffered is classified as 2 and the duration of suffering is more than 1 year to five years. 
Table 2a. SRQ CHD Client Results

\begin{tabular}{|l|c|c|c|c|}
\hline \multirow{2}{*}{ Mental Status } & \multicolumn{2}{c|}{ Intervention } & \multicolumn{2}{c|}{ Control } \\
\cline { 2 - 5 } & Pre test & Post Test & Pre test & Post test \\
\hline Symptoms of Neurosis & 2 & 11 & 12 & 10 \\
\hline Psychotic Symptoms & 15 & 2 & 1 & 1 \\
\hline PSTD & 3 & - & - & - \\
\hline Normal & 80 & 87 & 87 & 89 \\
\hline
\end{tabular}

Tabel 2b. Results of Independent Physical Examination of CHD Clients

\begin{tabular}{|l|c|c|c|c|}
\hline \multirow{2}{*}{ Physical condition } & \multicolumn{2}{|c|}{ Intervention } & \multicolumn{2}{c|}{ Control } \\
\cline { 2 - 5 } & Pre test & Post Test & Pre test & Post test \\
\hline Normal & 41 & 66 & 74 & 77 \\
\hline Abnormal & 7 & - & 9 & 7 \\
\hline
\end{tabular}

Tabel 2.c. Equivalence Analysis of CHD History, CHD Classification and Duration of Suffering from CHD between Groups

\begin{tabular}{|l|c|c|c|c|c|}
\hline \multirow{2}{*}{ Variable } & \multicolumn{2}{|c|}{ Intervention } & \multicolumn{2}{|c|}{ Control } & \multirow{2}{*}{ P - value } \\
\cline { 2 - 5 } & $\mathrm{N}$ & $\%$ & $\mathrm{~N}$ & $\%$ & \\
\hline Previous CHD history & & & & & $\mathbf{0 . 0 0 2}$ \\
- Yes & 87 & 87 & 99 & 99 & \\
- No & 13 & 13 & 1 & 1 & \\
\hline Classification of CHD suffered & & & & & $\mathbf{1 . 0 0 0}$ \\
- APSCCS I & & & & & \\
- APSCCS II & 88 & 88 & 87 & 87 & \\
& 12 & 12 & 13 & 13 & \\
\hline Length of time suffering from CHD & & & & & \multirow{2}{*}{$\mathbf{0 . 0 0 1}$} \\
- <6 Month & & & & & \\
- 6 Month-<1 Year & 9 & 9 & 17 & 17 & \\
- 1-5 Year & 19 & 19 & 35 & 35 & \\
- 5 Year & 36 & 36 & 39 & 39 & \\
- None & 23 & 23 & 8 & 8 & \\
& 13 & 13 & 1 & 1 & \\
\hline
\end{tabular}

Tabel 2.c. The Effect of Respondent Characteristics on the Level of Knowledge, Skills, and Self-Recovery in the Treatment of CHD

\begin{tabular}{clllll}
\hline $\begin{array}{c}\text { Variabel } \\
\text { Independent }\end{array}$ & $\begin{array}{c}\text { Variabel } \\
\text { Dependent }\end{array}$ & $\begin{array}{c}\text { Mean } \\
\text { Square }\end{array}$ & df & F & P-value \\
\hline Age & $\bullet$ Knowledge & 31.057 & 1 & 14.828 & $\mathbf{0 . 0 0 1}$ \\
& $\bullet$ Skills & 26.659 & 1 & 13.802 & $\mathbf{0 . 0 0 1}$ \\
& - Self & 20.815 & 1 & 17.304 & $\mathbf{0 . 0 0 1}$ \\
& Recovery & & & & \\
\hline
\end{tabular}

The main findings in this study were respondents aged 57-74 years, known from the results of the SRQ 21 independent survey and the results of self-identification of the physical condition of CHD clients. Based on the results of the multivariate test 
above, it was found that the age of the CHD client had an effect on knowledge, skills and self-recovery in CHD care in the application of MD My Friend.

At the end of the study, it is hoped that found that MD-My Friend has an effect on reducing anxiety $\mathrm{CHD}$ Clients in the Community. The results of the statistical analysis on the respondent's ability in Knowledge, Skills, and Self-Recovery have very significant findings with a P-Value of 0.001. These results indicate that CHD Clients who experience stress, through video intervention MD My Friend can reduce their stress conditions and anticipate efforts to reduce the high risk of the main cause of death.

The main purpose of this study is to prove that MD My Friend has an effect on reducing anxiety CHD Clients in the Community. The self-recovery ability of CHD clients which has an age range is known from the results of the SRQ 21 independent survey and the results of self-identification of the physical condition of CHD clients. On examination before and after the intervention for the results of SRQ 21 the intervention group mostly normal results as well as in the control group. While the physical conditions identified independently by the client on examination before and after the intervention in the intervention group were mostly in normal conditions and in the control group.

The results in table 2.a, 2.b. and 2.c. find of the analysis showed that there were differences in the history of previous CHD and the duration of suffering from CHD in the respondents between the intervention group and the control group. Meanwhile, the classification of CHD suffered by respondents did not differ between the intervention group and the control group. The results of the analysis showed that there were differences in the history of previous CHD and the duration of suffering from CHD in the respondents between the intervention group and the control group. Meanwhile, the classification of CHD suffered by respondents did not differ between the intervention group and the control group.

Based on the results of the multivariate test, it is known that the age of the CHD client has an effect on knowledge, skills and self-recovery in CHD treatment on the application of MD My Friend with a P-Value of 0.001. Conditions Stress is often associated with an increased risk of coronary heart disease (CHD) but the mechanism underlying this relationship remains unclear. Stress can affect CHD through direct activation of neuroendocrine responses to stressors, or more indirectly through unhealthy behaviors that increase CHD risk, such as smoking, lack of exercise, or excessive alcohol consumption. (Petra H Wirtz and Roland von Känel). In the results of this study analysis showed there are significant differences in knowledge scores, skills and skills self-recovery in self CHD care in the intervention group before and after the intervention of the implementation of MD My Friend (value $p=0.001$ ), these results state that the independence of the PJK Client who has been able to overcome his anxiety by facilitating MD My Friend for 3 days a week and the Client's ability to monitor his own blood pressure including regulating his diet and also his activities.

Limitations of this study, including when measuring self-monitoring. This condition is because the Client does it himself, although some are monitored by health 
cadres in their respective regions. Generalizations with benefits for other health educators around the world can be done external validity of the results of the study, such as a breakthrough innovation in aligning independent CHD clients in monitoring their health status, as a step for the rehabilitation phase of health services, and the main thing is the possibility to reduce CHD mortality in the community.

\section{CONCLUSION}

The conclusion from the results of MD My Friend's action research, from 200 respondents aged 57-74 years, having knowledge has been able to master knowledge, especially the skill of independent health monitoring has a significant effect. As research or further study, we recommend following up on self-monitoring with video innovations implemented in hospitals/clinics, especially for education and/or healthcare practices.

\section{ACKNOWLEDGMENTS}

The Director of Poltekkes Kemenkes Jakarta I and the academic community who have helped support us since the preparation of the proposal, administration, consultation, to the implementation of this research.

\section{REFERENCES}

1. Ahuja, N. (2019). Roles and Responsibilities of a Cardiac Rehabilitation Nurse. Retrieved from https://medium.com/@nancyahuja1/roles-and-responsibilities-of-a-cardiacrehabilitation-nurse-5bf101a7d737

2. Celano, C. M., Daunis, D. J., Lokko, H. N., Campbell, K. A., \& Huffman, J. C. (2016). Anxiety disorders and cardiovascular disease. Curr Psychiatry, 18(11), 101-120. https://doi.org/10.1007/s11920-016-0739-5

3. Davis, S. M., Koch, G. G., Davis, C. E., \& LaVange, L. M. (2003). Statistical approaches to effectiveness measurement and outcome-driven re-randomizations in the Clinical Antipsychotic Trials of Intervention Effectiveness (CATIE) studies. $\begin{array}{lll}\text { Schizophrenia } \quad \text { Bulletin, } & \text { 73-80. }\end{array}$ https://doi.org/10.1093/oxfordjournals.schbul.a006993

4. De Ridder, B., Van Rompaey, B., Kampen, J. K., Haine, S., \& Dilles, T. (2018). Smartphone Apps Using Photoplethysmography for Heart Rate Monitoring: MetaAnalysis. JMIR Cardio, 2(1). https://doi.org/10.2196/cardio.8802

5. Dimsdale, J. E. (2008). Psychological Stress and Cardiovascular Disease. Journal of the American College of Cardiology, 51(13), 1237-1246. https://doi.org/10.1016/j.jacc.2007.12.024

6. Kaplan, A. M., \& Haenlein, M. (2010). Users of the world, unite! The challenges and opportunities of Social Media. Business Horizons, 53(1), 59-68. https://doi.org/10.1016/j.bushor.2009.09.003

7. Kerry Ressler, Daniel Pine, B. R. (2015). Anxiety Disorders. Oxford University Press. https://doi.org/10.1093/med/9780199395125.001.0001 
8. Reid, J., Ski, C. F., \& Thompson, D. R. (2013). Psychological Interventions for Patients with Coronary Heart Disease and their Partners: A Systematic Review. PloS one, 8(9), 1-13. https://doi.org/10.1371/journal.pone.0073459

9. Roest, A. M., Martens, E. J., de Jonge, P., \& Denollet, J. (2010). Anxiety and Risk of Incident Coronary Heart Disease. A Meta-Analysis. Journal of the American College of Cardiology, 56(1), 38-46. https://doi.org/10.1016/j.jacc.2010.03.034

10. Roring, J. (2019). Prixa, Platform Manajemen Kesehatan berbasis AI Pertama dari Indonesia untuk Indonesia. Retrieved from https://www.jurnas.com/artikel/62627/Prixa-Platform-Kesehatan-PertamaBerbasis-AI-di-Indonesia/

11. Schneider, R. H., Grim, C. E., Rainforth, M. V., Kotchen, T., Nidich, S. I., GaylordKing, C., Salerno, J. W., Kotchen, J. M., \& Alexander, C. N. (2012). Stress reduction in the secondary prevention of cardiovascular disease: Randomized, controlled trial of transcendental meditation and health education in blacks. Circulation: Cardiovascular Quality and Outcomes, 5(6), 750-758. https://doi.org/10.1161/CIRCOUTCOMES.112.967406

12. Suryanto, F. (2017). Deteksi Denyut Nadi Manusia Berbasis Photoplethysmography (PPG) pada Video Menggunakan Discrete Fourier Transform (DFT). (Masters Thesis, Institut Teknologi Sepuluh Nopember).

13. Watkins, L. L., Koch, G. G., Sherwood, A., Blumenthal, J. A., Davidson, J. R. T., O'Connor, C., \& Sketch, M. H. (2013). Association of Anxiety and Depression with all-cause Mortality in Individuals with Coronary Heart Disease. Journal of the American Heart Association, 2(2). https://doi.org/10.1161/JAHA.112.000068

14. Worboys, M. (2013). The Hamilton Rating Scale for Depression: The Making of a "Gold Standard" and the Unmaking of a Chronic Illness, 1960-1980. Chronic Illness, 9(3), 202-219. https://doi.org/10.1177/1742395312467658

15. Zvolensky, M. J., Bakhshaie, J., \& Brandt, C. (2015). Anxiety Disorders and Cardiovascular Illness. Anxiety Disorders, 18(11), 267-280. https://doi.org/10.1093/med/9780199395125.003.0019 